\title{
Effects of Chromium Picolinate and Ascorbic Acid Dietary Supplementation on Nitrogen and Mineral Excretion of Laying Hens Reared in a Low Ambient Temperature $\left(7^{\circ} \mathrm{C}\right)$
}

\author{
K. SAHIN ${ }^{1}$, N. SAHIN ${ }^{2}$
}

${ }^{1}$ Department of Animal Nutrition, Faculty of Veterinary, University of Firat, 23100 Elazıg, Turkey

${ }^{2}$ Veterinary Control and Research Institute

Received November 26, 2001

Accepted June 19, 2002

\section{Abstract}

Sahin K., N. Sahin: Effects of Chromium Picolinate and Ascorbic Acid Dietary Supplementation on Nitrogen and Mineral Excretion of Laying Hens Reared in a Low Ambient Temperature $\left(7^{\circ} \mathrm{C}\right)$. Acta Vet. Brno 2002, 71: 183-189.

The effects of chromium (chromium picolinate, CrPic) and ascorbic acid (L-ascorbic acid) supplementation on nitrogen $(\mathrm{N})$, ash and mineral retention in laying hens (Hy-Line) reared under a low ambient temperature $\left(7^{\circ} \mathrm{C}\right)$ was evaluated. One hundred and twenty laying hens (32-weekold) were divided into four groups, 30 hens per group. The laying hens were fed either a basal diet or the basal diet supplemented with either $400 \mu \mathrm{g}$ of $\mathrm{Cr} / \mathrm{kg}$ of diet, $250 \mathrm{mg}$ of L-ascorbic acid $/ \mathrm{kg}$ of diet, or $400 \mu \mathrm{g}$ of $\mathrm{Cr}$ plus $250 \mathrm{mg}$ of L-ascorbic acid/kg of diet. Retention of N, ash, Ca, P, Zn, $\mathrm{Fe}$ and $\mathrm{Cr}$ were highest with the combination of chromium and ascorbic acid and were lowest with the control diet $(P<0.05)$. Accordingly, excretion of $\mathrm{N}$, ash $\mathrm{Ca}, \mathrm{P}, \mathrm{Zn}, \mathrm{Fe}$ and $\mathrm{Cr}$ was lesser in chromium and ascorbic acid supplemented groups than the control $(P<0.05)$, that of combination of supplemental chromium and ascorbic acid being lowest. Results of the present study show that supplementing ascorbic acid and chromium, particularly as a combination, improved retention of mineral and decreased excretion of nitrogen, ash, $\mathrm{Ca}, \mathrm{P}, \mathrm{Zn}, \mathrm{Fe}$, and $\mathrm{Cr}$ in laying hens. Such a combination of supplementation can offer a potential protective management practice in preventing the detrimental effects of cold stress in laying hens. The results of the present study also show that chromium and vitamin $\mathrm{C}$ had additive effects on parameters measured at the present study.

Cold stress, chromium, ascorbic acid, mineral excretion, laying hen

Low ambient temperature causes some adverse effects including increased feed intake, and decreased egg production, nutrient digestibility, and feed efficiency in poultry ( Sagher 1975; Arad and Marder 1982; Ensminger et al. 1990; Spinu and Degen 1993; Sari 1993). Enviromental stress causes deficiencies in vitamin $C$ (ascorbic acid) and chromium for poultry (McDowell 1989; NRC, 1997; Sahin and S ahin 2001). It has been reported that dietary ascorbic acid and chromium requirement in poultry was significantly affected by thermal stress and the negative effects of stress were prevented by ascorbic acid and chromium supplementation (McDowell 1989; Mowat 1994; NRC 1997; Sahin and Kucuk 2001; Sahin et al. 2001a; Sahin et al. 2002a). Dietary chromium supplementation has been shown to positively affect growth rate and feed efficiency of growing poultry (Cupo and Donaldson 1987; NRC 1997; Lien et al. 1999; Sahin et al. 2001b). These beneficial effects of $\mathrm{Cr}$ can be observed more efficiently under environmental, dietary, and hormonal stress (Anderson 1994; Wright et al. 1994). Supplemental dietary chromium is also recommended by NRC (1997) for animals undergoing environmental stress. Chromium stimulates and regulates the action of insulin (Anderson 1994; Mowat 1994) which is involved in anabolic processes (Colgan 1993). Also, through increasing the effectiveness of insulin, $\mathrm{Cr}$ indirectly potentiates

Address for correspondence:

Dr. Kazım Sahin,

Veteriner Kontrol ve Arastırma Enstitüsü Loj.

23100 Elazıg/TURKEY
Phone: 0-424-2370000/3213

http://www vfu.cz/acta-vet/actavet htm 
ascorbic acid transportation (Mann and Newton 1975; Seaborn et al. 1994). In addition, chromium is thought to be essential for activating certain enzymes and for stabilizing proteins and nucleic acids (Anderson 1987; Linder 1991).

Ascorbic acid functions as a reducing agent and as an antioxidant. Previous studies have shown that ascorbic acid is an indispensable micronutrient required to maintain the physiological processes of certain animals including poultry (McDowell 1989). Poultry are known not to require a dietary source of vitamin $\mathrm{C}$ because of the ability of birds to synthesize its own. Pardue and Thaxton (1986) have documented evidence that particular environmental stressors can alter ascorbic acid utilization or synthesis in avian species. It has been also reported that ascorbic acid synthesis is inadequate under stress conditions such as low or high environmental temperatures, humidity, high production rates, and parasitic infestation (Sykes 1978; Hornig et al. 1984; McDowell 1989; Cheng et al. 1990). Several researches have documented a beneficial effect of ascorbic acid supplementation on growth rate and egg production in stressed-poultry (Thornton 1962; McDowell 1989; Bains 1996). At temperatures above or below thermoneutral zone, corticosteroid secretion increases in response to stress (Brown and Nestor 1973). By decreasing synthesis and secretion of corticosteroids, vitamin $\mathrm{C}$ alleviates the negative effects of stress such as cold stress-related depression in poultry performance (McDowell 1989). In evaluating the effects of supplemental chromium and ascorbic acid, nitrogen, ash and mineral excretion and retention have a substantial merit in understanding metabolic changes in cold-stressed poultry. Therefore, the objective of this study was to evaluate the effects of chromium and ascorbic acid supplementation on retention and excretion of nitrogen, ash and minerals in laying hens reared under a low ambient temperature $\left(7^{\circ} \mathrm{C}\right)$.

Animals

\section{Materials and Methods}

One hundred and twenty 32-week-old Hy-Line laying hens were obtained from a commercial company recognized by Ministry of Agriculture, Turkey. No animal losses were observed throughout the experiment. The experiment was in accordance with animal welfare, and was conducted under protocols approved by the Veterinary Control and Research Institute of Elazig-Turkey.

Dietary Treatments and Experimental Design

The laying hens were fed the basal diet or the basal diet supplemented with either $400 \mu \mathrm{g}$ of $\mathrm{Cr} / \mathrm{kg}$ of diet, 250 $\mathrm{mg}$ of L-ascorbic acid $/ \mathrm{kg}$ of diet, or $400 \mu \mathrm{g}$ of $\mathrm{Cr}$ plus $250 \mathrm{mg}$ of L-ascorbic acid $/ \mathrm{kg}$ of diet. Ascorbic acid (ROVIMIX ${ }^{\circledR}$ STAY-C ${ }^{\circledR} 35$ ) was specifically produced as a stabilized source of vitamin C for feed by a commercial company (Roche, Levent-Istanbul). Chromium Picolinate (CrPic, Chromax ${ }^{\circledR}$, Prince Agri Products) was used as chromium source. Ingredients and chemical composition of the basal diet are shown in Table 1 . The basal diet was a typical layer diet containing $11.6 \mathrm{MJ} / \mathrm{kg}$ and $17.6 \%$ crude protein, and was calculated to meet or slightly exceed the nutrient requirements recommended by the National Research Council (1994).

The hens were randomly assigned to four groups, 30 hens each, according to their egg production which were similar among treatments. Water and the diets were offered ad libitum. The hen house was lit for $17 \mathrm{~h}$ per day. During the experiment, hen house's temperature and humidity were measured four times a day (at 06.00, 12.00, 18.00 , and $24.00 \mathrm{~h}$ ). Average ambient relative humidity inside the hen house was $64 \pm 7 \%$. The mean value of daily temperature in the hen house was $7 \pm 3{ }^{\circ} \mathrm{C}$. Diets were fed for $15 \mathrm{wk}$ between October $15^{\text {th }}$ and January $30^{\text {th }}$.

Retention and Excretion of Nitrogen and Minerals

At the end of experiment, 6 hens per treatment were individually caged to determine retention and excretion of dietary nutrients at the same low temperature. Nutrient retention was the amount retained per hen per day and was calculated based on feed consumption and the calculated analysis of the nutrient in the feed. Excreta of hens were collected for 3 days.

Laboratory Analyses

Chemical analysis of the diet and excrement samples were run using international procedures of AOAC (1990). Excrement $\mathrm{N}$ was chemically analyzed according to the method of Terpstra and de Hart (1974). To determine concentrations of $\mathrm{Ca}, \mathrm{Zn}, \mathrm{Fe}$, and $\mathrm{Cr}$, diet and excreta were dry-ashed (AOAC, 1990). Concentrations of Cr in diet and excrement samples were measured using atomic absorption spectrometer containing a graphite furnace and graphite tubes (Shimadzu AA-660-GFA-4B-P/N 204-03154-02). Calcium, Zn, and Fe concentrations were 
Table 1

Ingredients and chemical composition of the basal diet fed to laying hens

\begin{tabular}{|l|c|}
\hline Ingredients & $\%$ \\
\hline Ground Corn & 63.05 \\
\hline Soybean Mea & 22.75 \\
\hline Wheat Bran & 1.68 \\
\hline Animal Fat & 1.50 \\
\hline Limestone & 8.54 \\
\hline Dicalcium Phosphate & 1.40 \\
\hline Vitamin Premix ${ }^{\mathrm{a}}$ & 0.25 \\
\hline Mineral Premix ${ }^{\mathrm{b}}$ & 0.20 \\
\hline DL-Methionine & 0.20 \\
\hline Sodium Chloride & 0.40 \\
\hline DM, $\%$ & 91.10 \\
\hline Chemical Analyses (DM basis) & \\
ME, MJ/kg & 11.6 \\
\hline Crude Protein, $\%$ & 17.6 \\
\hline Calcium, $\%$ & 4.2 \\
\hline Phosphorus, $\%$ & 0.8 \\
\hline Zinc, $\mathrm{mg} / \mathrm{kg}$ & 28 \\
\hline Iron, $\mathrm{mg} / \mathrm{kg}$ & 36 \\
\hline Chromium, $\mu \mathrm{g} / \mathrm{kg}$ & 1.1 \\
\hline
\end{tabular}

aMix supplied per $2 \mathrm{~kg}$ of diet: vitamin A, $15.500 \mathrm{IU}$; cholecalciferol, $2.500 \mathrm{IU}$; vitamin E, 15.5 IU; menadione, $2 \mathrm{mg}$; thiamin, $0.5 \mathrm{mg}$; riboflavin, $7 \mathrm{mg}$; d-pantothenic acid, $8 \mathrm{mg}$; pyrodixine, $2 \mathrm{mg}$; vitamin $\mathrm{B}_{12} 0.15 \mathrm{mg}$; folic acid, $1.5 \mathrm{mg}$; niacin, $30 \mathrm{mg}$.

${ }^{\mathrm{b}}$ Mix supplied per $2 \mathrm{~kg}$ of diet: $\mathrm{Mn}, 80 \mathrm{mg}$; Fe, $60 \mathrm{mg}$; Zn, $50 \mathrm{mg}$; Cu, $7 \mathrm{mg}$; Iodine, $0.3 \mathrm{mg}$; Se, $0.15 \mathrm{mg}$; choline chloride, $400 \mathrm{mg}$.

${ }^{c}$ Calculated from the tabular values (NRC, 1994).

measured at specific wavelengths for each element by using atomic absorption spectrometer. Calibrations for the mineral assays were conducted with a series of mixtures containing graded concentrations of standard solutions of each element.

Statistical Analyses

All data were analyzed by one-way ANOVA (GLM procedure of SAS; SAS Institute, 1996) to test for the effects of the dietary treatments. When a significant treatment effect was observed, a Duncan's new multiple range test was used to compare means. Treatment effects were considered with the significant level at $P<0.05$. Experimental unit was individual bird.

\section{Results}

The effects of supplemental dietary chromium and ascorbic acid on excretion and retention of nitrogen, ash and mineral in laying hens when exposed to a cold environment are shown in Table 2. A combination of chromium and ascorbic acid, rather than each separately, provided the greater nitrogen and mineral retention and lower excretion rates in laying hens exposed to a cold environment compared to the control group. Retention of $\mathrm{N}$, ash, $\mathrm{Ca}, \mathrm{P}, \mathrm{Zn}$, $\mathrm{Fe}$ and $\mathrm{Cr}$ were highest with the combination of chromium and ascorbic acid and were lowest with the control diet $(P<0.05)$. Accordingly, excretion of $\mathrm{N}$, ash, $\mathrm{Ca}, \mathrm{P}, \mathrm{Zn}, \mathrm{Fe}$ and $\mathrm{Cr}$ was lesser in the chromium and ascorbic acid supplemented groups than the control $(P<0.05)$, that of a combination of supplemental chromium and ascorbic acid being the lowest.

\section{Discussion}

It is known that poultry performance and nutrient digestibility decrease when ambient temperature goes below the thermo-neutral zone (Arad and Marder 1982; Ensminger et al. 1990; Sari 1993). At such temperatures, corticosteroid secretion increases in 
Table 2

The effects of supplemental chromium and ascorbic acid on the nitrogen and minerals retention and excretion of laying hens reared at a low ambient temperature $(n=6)$

\begin{tabular}{|c|c|c|c|c|c|}
\hline \multirow{2}{*}{ Item } & \multicolumn{5}{|c|}{ Treatments* } \\
\hline & $\mathrm{C}$ & $\mathrm{Cr}$ & Vit C & $\mathrm{Cr}+\mathrm{Vit} \mathrm{C}$ & SEM \\
\hline $\begin{array}{l}\text { Retention } \\
\text { Nitrogen, (g/hen/d, DM) }\end{array}$ & $1.9^{\mathrm{c}}$ & $2.4^{\mathrm{b}}$ & $2.3^{\mathrm{b}}$ & $2.7^{\mathrm{a}}$ & 0.09 \\
\hline Ash, (g/hen/d, DM) & $6^{\mathrm{c}}$ & $9^{b}$ & $9^{\mathrm{b}}$ & $13^{\mathrm{a}}$ & 0.5 \\
\hline Calcium, (g/hen/d, DM) & $2^{\mathrm{c}}$ & $3^{\mathrm{b}}$ & $3^{\mathrm{b}}$ & $4^{\mathrm{a}}$ & 0.02 \\
\hline Phosphorus, (g/hen/d, DM) & $0.2^{\mathrm{c}}$ & $0.3^{\mathrm{b}}$ & $0.3^{\mathrm{b}}$ & $0.4^{\mathrm{a}}$ & 0.005 \\
\hline Zinc, (mg/hen/d, DM) & $1^{\mathrm{c}}$ & $2^{b}$ & $2^{b}$ & $3^{a}$ & 0.2 \\
\hline Iron, (mg/hen/d, DM) & $10^{\mathrm{c}}$ & $13^{b}$ & $14^{\mathrm{b}}$ & $17^{\mathrm{a}}$ & 1 \\
\hline Chromium, (mg/hen/d,DM) & $0.05^{\mathrm{c}}$ & $0.07^{\mathrm{b}}$ & $0.07^{\mathrm{b}}$ & $0.08^{\mathrm{a}}$ & 0.001 \\
\hline $\begin{array}{l}\text { Excretion } \\
\text { Nitrogen (g/hen/d, DM) }\end{array}$ & $1.6^{\mathrm{a}}$ & $1.5^{\mathrm{b}}$ & $1.5^{\mathrm{b}}$ & $1.3^{\mathrm{c}}$ & 0.003 \\
\hline Ash, (g/hen/d, DM) & $10^{\mathrm{a}}$ & $9^{b}$ & $9^{b}$ & $8^{c}$ & 0.2 \\
\hline Calcium, (g/hen/d, DM) & $2.5^{\mathrm{a}}$ & $2.4^{\mathrm{b}}$ & $2.4^{\mathrm{b}}$ & $2.3^{\mathrm{c}}$ & 0.05 \\
\hline Phosphorus, (g/hen/d, DM) & $0.6^{\mathrm{a}}$ & $0.5^{\mathrm{b}}$ & $0.5^{\mathrm{b}}$ & $0.4^{\mathrm{c}}$ & 0.002 \\
\hline Zinc, (mg/hen/d, DM) & $11^{\mathrm{a}}$ & $10^{\mathrm{b}}$ & $10^{b}$ & $8^{\mathrm{c}}$ & 0.03 \\
\hline Iron, (mg/hen/d, DM) & $36^{\mathrm{a}}$ & $33^{\mathrm{b}}$ & $32^{b}$ & $30^{\mathrm{c}}$ & 0.9 \\
\hline Chromium, $(\mu \mathrm{g} / \mathrm{hen} / \mathrm{d}, \mathrm{DM})$ & $0.09^{\mathrm{a}}$ & $0.07^{\mathrm{b}}$ & $0.07^{b}$ & $0.06^{\mathrm{c}}$ & 0.005 \\
\hline
\end{tabular}

a,b,cd: Mean values within a row with no common superscript differ significantly $(P<0.05)$.

$* \mathrm{C}$ : control (basal) diet, Cr: control diet $+400 \mu \mathrm{g}$ of $\mathrm{Cr} / \mathrm{kg}$, Vit C: control diet $+250 \mathrm{mg}$ of L-ascorbic acid $/ \mathrm{kg}$ of diet, $\mathrm{Cr}+\mathrm{Vit} \mathrm{C}$ : control diet $+400 \mu \mathrm{g}$ of $\mathrm{Cr} / \mathrm{kg}+250 \mathrm{mg}$ of $\mathrm{L}$-ascorbic acid $/ \mathrm{kg}$.

response to stress (Brown and Nestor 1973). Kutlu and Forbes (1993) reported that ascorbic acid reduces the synthesis of corticosteroid hormones in birds. By decreasing synthesis and secretion of corticosteroids, vitamin $C$ alleviates the negative effects of environmental stress such as cold stress-related depression in poultry performance (McDowell 1989; Pardue et al.1985). Environmental stress has been shown to increase mineral excretion (S mith and Teeter 1987). El-Husseiny and Creger (1981) found that broilers reared under environmental stress had lower rates of $\mathrm{Ca}, \mathrm{Cu}, \mathrm{Fe}, \mathrm{K}, \mathrm{Mg}, \mathrm{Mn}, \mathrm{Na}$, $\mathrm{P}$, and $\mathrm{Zn}$ retention. Stress increases chromium mobilization from tissues and its excretion and also depresses ascorbic acid synthesis (Sykes 1978; Hornig et al. 1984; Borel at al. 1984; Pardue and Thaxton 1986; Anderson 1987; McDowell 1989); thus stress may exacerbate a marginal chromium and ascorbic acid deficiency or an increased chromium and ascorbic acid requirement, implying that both chromium and ascorbic acid should be supplemented as shown in the present study. Wallis and Balnave (1984) found that the digestibility of amino acids was decreased by a high environmental temperature in broilers. Similarly, Zuprizal et al. (1993) have shown that true digestibility of protein and amino acids decreased as the temperature increased from 21 to $32{ }^{\circ} \mathrm{C}$. The results of the current metabolic trial showed that retention of nitrogen and $\mathrm{Ca}$, $\mathrm{P}, \mathrm{Zn}, \mathrm{Fe}$ as well as $\mathrm{Cr}$, is improved and excretion, decreased by supplemental chromium and ascorbic acid. We cannot explain the decrease observed in chromium excretion in chromium supplemented groups (Table 2). A chromium supplementation at a higher level could increase the excretion of chromium. Since ascorbic acid and chromium (postulated to be antioxidants) have a protective effect on pancreatic tissue against oxidative damage (McDowell 1989; Preuss et al. 1997), they may help pancreas to function properly including secretions of digestive enzymes, thus improving retention of nitrogen and minerals. In a previous a study we found that ascorbic acid supplementation reduced 
serum concentration of malonaldehyde (MAL), an indicator of lipid peroxidation, in stressed hens (S a hin et al. 2002b). An increase in retention of nutrients in laying hens in the present study could have been due to such positive effects of ascorbic acid and/or chromium. It has also been reported that in stressed-mice, loss of zinc, copper, iron and manganese was reduced by supplemental chromium (Schrauzer et al. 1986). S ahin and Sahin (2001) reported a decrease in utilization of dry matter, crude protein, and ether extract in laying hens kept under low ambient temperature $\left(6.2^{\circ} \mathrm{C}\right)$ and that supplemental chromium and vitamin $\mathrm{C}$ alleviated these negative values to a higher extent than control group. Sahin and Kücük (2001) reported that digestibility of nutrients increased with dietary vitamin $\mathrm{C}$ in Japanese quail under stress conditions.

In the present study, the magnitude of the increases or decreases in retention and excretion of nitrogen, ash and minerals was greater when a combination of ascorbic acid and chromium was supplemented than when supplemented separately. These results revealed additive effects of ascorbic acid and chromium, indicating that ascorbic acid and chromium work together or act synergistically. Similarly, Carol et al. (1994) found an interaction between $\mathrm{Cr}$ and vitamin $\mathrm{C}$ on bone and brain $\mathrm{Mn}$ retention and distribution in guinea pigs, and stated that dietary $\mathrm{Cr}$ may influence ascorbic acid metabolism via protecting ascorbate from oxidative destruction. In addition, insulin is known to play a role in ascorbic acid transportation in red blood cells, and glucose competitively inhibits ascorbic acid transport (Mann and Newton 1975). Through increasing the effectiveness of insulin, chromium indirectly promotes the ascorbic acid transportation (Seaborn et al. 1994).

Results of the present study show that supplementing ascorbic acid and chromium, particularly as a combination, improved retention of mineral and decreased excretion of nitrogen, ash, $\mathrm{Ca}, \mathrm{P}, \mathrm{Zn}, \mathrm{Fe}$, and $\mathrm{Cr}$ in laying hens. Such a combination of supplementation can offer a potential protective management practice in preventing the detrimental effects of cold stress on laying hens.

Vliv doplnění diety chrómpikolinátem a kyselinou askorbovou na exkreci dusíku a minerálních látek nosnicemi odchovávanými při nízké teplotě prostředí $\left(7^{\circ} \mathrm{C}\right)$

V práci byl hodnocen účinek doplnění diety chrómem (chrómpikolinát, CrPic) a kyselinou askorbovou (L-askorbová kyselina) na retenci dusíku (N), popelovin a minerálních látek u nosnic (linie HY) odchovávaných při nízké teplotě okolního prostř̌edí $\left(7{ }^{\circ} \mathrm{C}\right)$. Skupina 120 nosnic (stáří 32 týdnů) byla rozdělena do 4 skupin, po 30 slepicích v jedné skupině. Nosnice byly krmeny jednak základní dietou, jednak základní dietou doplněnou $400 \mu \mathrm{g} \mathrm{Cr} / \mathrm{kg}$ krmiva nebo $250 \mathrm{mg} \mathrm{L} \mathrm{-} \mathrm{askorbové} \mathrm{kyseliny/kg} \mathrm{krmiva} \mathrm{anebo}$ $400 \mu \mathrm{g} \mathrm{Cr}$ a současně $250 \mathrm{mg}$ L-askorbové kyseliny/kg krmiva.

Nejvyšší retence $\mathrm{N}$, popelovin, $\mathrm{Ca}, \mathrm{P}, \mathrm{Zn}, \mathrm{Fe}$ a $\mathrm{Cr}$ byla zaznamenána u kombinace chrómu a kyseliny askorbové a nejnižší byla u kontrolní diety $(P<0.05)$. Podobně tomu bylo i u exkrece $\mathrm{N}$, popelovin, $\mathrm{Ca}, \mathrm{P}, \mathrm{Zn}$, Fe a $\mathrm{Cr}$ : nejnižší byla u skupin krmených $\mathrm{s}$ doplňkem chrómu a kyselinou askorbovou ve srovnání s kontrolní skupinou $(P<0.05)$. Z výsledků studie je zřejmé, že doplnění výživy kyselinou askorbovou a chrómem, zvláště $\mathrm{v}$ kombinaci obou, zlepšuje retenci minerálních látek a snižuje sekreci $\mathrm{N}$, popelovin, $\mathrm{Ca}$, $\mathrm{P}, \mathrm{Zn}, \mathrm{Fe}$ a Cr u nosnic. Uvedená kombinace jako krmný doplněk by mohla mít př́ípadný protektivní účinek při prevenci škodlivých následků chladového stresu u nosnic. Výsledky této studie rovněž dokládají, že chróm a vitamín $\mathrm{C}$ měly aditivní účinek na sledované ukazatele. 


\section{References}

AOAC 1990: Official Methods of Analysis (15th ed.). Association of Official Analytical Chemists, Arlington, VA ANDERSON, RA 1987: Chromium. Trace Elements in Human and Animal Nutrition. Academic Press, New York, pp. $225-244$

ANDERSON, RA 1994: Stress effects on chromium nutrition of humans and farm animals. In: Lyons, TP and Jacques, KA (Eds), Biotechnology in Feed Industry. University Press, Nottingham, England, pp. 267-274

ARAD, Z, MARDER, J 1982: Comparison of the productive performances of the sinai bedouin fowl, the white leghorn and their crossbreds: Study under natural desert conditions. Brit Poultry Sci 23: 333-338

BAINS BS, 1996: The role of vitamin C in stress management. Misset World Poultry 12: 38-42

BOREL, JS, MAJERUS, TC, POLANSKY, M, MOSER, PB, ANDERSON, RA 1984: Chromium intake and urinary chromium excretion of trauma patients. Biol Trace Elem Res 6, 317-321

BROWN, KI, NESTOR, KE 1973: Some physiological responses of turkeys selected for high and low adrenal response to cold stress. Poultry Sci 52: 1948-1954

CAROL, DS, CHENG, N, ADELEYE, B, OWENS, F, STOECKER, BJ 1994: Chromium and chronic ascorbic acid depletion effects on tissue ascorbate, manganese, and ${ }^{14} \mathrm{C}$ retention from ${ }^{14} \mathrm{C}$-ascorbate in guinea pigs. Biol Trace Elem Res 41: 279- 285

CHENG, TK, COON, CN, HAMRE, ML 1990: Effect of environmental stress on the ascorbic acid requirement of laying hens. Poultry Sci 69: 774-780

COLGAN, M 1993: Chromium boosts insulin efficiency. In: Optimum Sports Nutrition. New York: Advanced Research Press, pp. 313-320

CUPO, MA, DONALDSON, WE, 1987: Chromium and vanadium effects on glucose metabolism and lipid synthesis in the chick. Poultry Sci 66: 120-126

EL HUSSEINY, O, CREGER, CR 1981: Effect of ambient temperature on mineral retention and balance of the broiler chicks. Poultry Sci. 60 (Supplement 1): 1651 (Abstract)

ENSMINGER, ME, OLDFIELD, JE, HEINEMANN WW 1990: Heinemann. Feeds and Nutrition. The Ensminger Publishing Company, USA, pp. 108-110

HORNIG, D, GLATTHAAR, B, MOSER, U 1984: General aspect of ascorbic acid function and metabolism In Workshop. Ascorbic Acid in Domestic Animals, I Wegger, FJ Tagwerker, J Moustgaard (Eds.), Royal Danish Agr Soc Copenhagen, pp. 3-24

KUTLU. HR, FORBES. JM 1993. Changes in growth and blood parameters in heat-stressed broiler chicks in response to dietary ascorbic acid. Livest Product Sci 36: 335-350

LIEN, TF, HORNG, YM, YANG KH 1999: Performance, serum characteristics, carcase traits and lipid metabolism of broilers as affected by supplement of chromium picolinate. Brit Poultry Sci 40: 357-363

LINDER, MC 1991: Nutrition and metabolism of the trace elements. in: nutritional biochemistry and metabolism with clinical applications. MC Linder (Ed.). Elsevier, New York, pp. 215-276

MANN, GV, NEWTON, P 1975: The membrane transport of ascorbic acid (El transporte de ácido ascórbico a las membranas celulares), Second Conference on Vitamin C, Annals of the New York Academy of Sciences. 258: 243-252

MCDOWELL, LR, 1989: Vitamins in Animal Nutrition. Comparative Aspects to Human Nutrition. Vitamin A and E. Mc Dowell LR (Ed.) Academic Press London, pp. 93-131.

MOWAT, DN 1994: Organic chromium. A new nutrient for stressed animals. Biotechnology in the Feed Industry: Proceedings of Alltech's Tenth Annual Symposium. Lyons, TP and Jacques KA (Eds). Nottingham University Press, Nottingham, UK, pp. 275-282

NRC 1994: Nutrient requirements of poultry. National Academy Press. Washington, D.C. Ninth Revised Edition.

NRC 1997: The role of chromium in animal nutrition. National Academy Press, Washington, D.C.

PARDUE, SL, THAXTON, JP, BRAKE J 1985: Influence of supplemental ascorbic acid on broiler performance following exposure to high environmental temperature. Poultry Sci 64: 1334-1341

PARDUE SL, THAXTON JP 1986: Ascorbic acid in poultry. A Review. World's Poultry Sci 42: 107-113

PREUSS, HG, GROJEC, PL, LIEBERMAN, S ANDERSON, RA 1997: Effects of different chromium compounds on blood pressure and lipid peroxidation in spontaneously hypertensive rats. Clin Nephrol 47: 325-330

SAGHER, BM, 1975: The effect of cold stress on muscle growth in young chicks. Growth 39: 281-285

SAHIN, K, KÜCÜK, O 2001: Effects of vitamin C and vitamin E on performance, digestion of nutrients, and carcass characteristics of Japanese quails reared under chronic heat stress $\left(34^{\circ} \mathrm{C}\right)$. J Anim Physiol and Anim Nutr 85: 335-342

SAHIN, K, KÜCÜK, O, SAHIN, N 2001a: Effects of dietary chromium picolinate supplementation on performance, insulin and corticosterone in laying hens under low ambient temperature. J Anim Physiol and Anim Nutr 85: 142-147

SAHIN, K, KÜCÜK, O, SAHIN, N, OZBEY, O 2001b: Effects of dietary chromium picolinate supplementation on egg production, egg quality, and serum concentrations of insulin, corticosterone and some metabolites of Japanese Quails. Nutrition Res 21: 1315-1321

SAHIN, N, SAHIN, K 2001: Optimal dietary concentrations of vitamin C and chromium picolinate for alleviating the effect of low ambient temperature $\left(6.2^{\circ} \mathrm{C}\right)$ on egg production, some egg characteristics, and nutrient digestibility in laying hens. Vet. Med. - Czech 46: 229-236 
SAHIN, N, ONDERCI, M, SAHIN, K 2002a: Effects of dietary chromium and zinc on egg production, egg quality and some blood metabolites of laying hens reared under low ambient temperature. Biol Trace Elem Res 85: 4758

SAHIN, K, SAHIN, N, YARALIOGLU, S 2002b: Effects of vitamin C and vitamin E on lipid peroxidation, blood serum metabolites, and mineral concentrations of laying hens reared at high ambient temperature. Biol Trace Elem Res 85: 35-45

SARI, M, 1993: Çevrenin evcil hayvanlarda besin maddesi ihtiyaçları üzerine etkileri. Yüksek Lisans Ders Notları, Elazig.

SAS Institute, 1996: SAS User's Guide: Statistics. SAS Institute Inc., Cary, NC.

SCHRAUZER, GN, SHRESTHA, KP MOLENAAR, TB, MEAD S 1989: Effects of chromium supplementation on food energy utilization and the trace element composition in the liver and heart of glucose-exposed young mice. Biol Trace Elem Res 9: 79-87

SEABORN CD, CHENG N, ADELEYE B, OWENS F, STOECKER BJ 1994: Chromium and chronic ascorbic acid depletion effects on tissue ascorbate, manganese, and 14C retention from 14C-ascorbate in guinea pigs. Biol Trace Elem Res 41: 279-285

SMITH, MO, TEETER, RG 1987: Potassium balance of the 5 to 8-week old boiler exposed to constant heat or cycling high temperature stress and the effects of supplemental potassium chloride on body weight gain and feed efficiency. Poultry Sci 66: 487-492

SPINU, M, DEGEN, AA, 1993: Effect of cold stress on performance and immune responses of bedouin and white leghorn hens. Brit Poultry Sci 34: 177-181

SYKES, AH 1978: Vitamin C for poultry; some recent research. Roche Symposium, pp:5-15

TERPSTRA, K, DE HART, N 1974. The estimation of urinary nitrogen and fecal nitrogen in poultry excreta. Z Tierphysiol Tierernaehr Futtemittlkd 32: 306-311

THORNTON, PA 1962: The effect of environmental temperature on body temperature and oxygen uptake by the chicken. Poultry Sci 41: 1053-1058

WALLIS, IR, BALNAVE, D 1984.The influence of environmental temperature, age and sex on the digestibility of amino acids in growing broiler chickens. Brit Poultry Sci 25: 401-407

WRIGHT, AJ, MOWAT, DN, MALLARD, BA 1994: Supplemental chromium and bovine respiratory disease vaccines for stressed feeder calves. Can J Anim Sci 74: 287-293

ZUPRIZAL, LARBIER, M, CHANNEAU, AM, GERAERT, PA 1993: Influence of ambient temperature on true digestibility of protein and amino acids of rapeseed and soybean meals in broilers. Poultry Sci 72: 289-295 